НАУКОВИЙ ВІСН

tific messenger of Lviv National Universily of

$\pi$

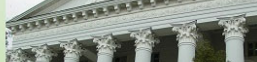

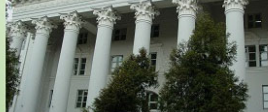

СЕРЯ "СЛЬСБКОГОСПОДАРСКК НАУКЕ

(3) (3)

2021
Науковий вісник Яьвівського національного університету ветеринарної медицини та біотехнодогій імені С.3. Гжицького. Серія: Сільськогосподарські науки

\author{
Scientific Messenger of Lviv National University
} of Veterinary Medicine and Biotechnologies. Series: Agricultural sciences

UDC 636.2.034.082

\title{
Relative variability of phenotypic traits and indicators of milk productivity of cows
}

\author{
Ye. I. Fedorovych ${ }^{1}$, V. V. Fedorovych ${ }^{1}$, P. V. Bodnar ${ }^{2}$, S. I. Fyl ${ }^{3}$, A. V. Dymchuk ${ }^{4}$, T. V. Orikhivskyj ${ }^{2}$ \\ ${ }^{1}$ Institute of Animal Biology NAAS, Lviv, Ukraine \\ ${ }^{2}$ Stepan Gzhytskyi National University of Veterinary Medicine and Biotechnologies Lviv, Ukraine \\ ${ }^{3}$ Dairy Global Experts LTD, Uman, Cherkasy region, Ukraine \\ ${ }^{4}$ Podilskyi State Agrarian Technical University, Kamyanets-Podilskyi, Ukraine
}

Article info

Received 24.05.2021

Received in revised form 28.06 .2021

Accepted 29.06.2021

Institute of animal biology NAAS, Vasyl Stus Str., 38, Lviv, 79034, Ukraine.

Tel.: +38-032-270-23-89

E-mail:logir@ukr.net

Stepan Gzhytskyi National University of Veterinary Medicine and Biotechnologies Lviv,

Pekarska Str., 50, Lviv,

79010, Ukraine

Dairy Global Experts LTD Ivana Honta Str., 3, Uman, Cherkasy region, 20343, Ukraine

Podilskyi State Agrarian Technical University, Shevchenko Str., 13, Kamyanets-Podilskyi, 32301

Ukraine.
Fedorovych, Ye. I., Fedorovych, V. V., Bodnar, P. V., Fyl, S. I., Dymchuk, A. V., \& Orikhivskyj, T. $V$. (2021). Relative variability of phenotypic traits and indicators of milk productivity of cows. Scientific Messenger of Lviv National University of Veterinary Medicine and Biotechnologies. Series: Agricultural sciences, 23(95), 101-107. doi: 10.32718/nvlvet-a9515

The research was conducted on cattle of Black-and-White breed (Holstein and Ukrainian Black-and-White dairy breed) at LLC "Veleten" Glukhiv district of Sumy region $(n=1956)$ and PJSC "Breeding Plant "Stepnoy" of Kamyansko-Dniprovsk district of Zaporizhzhia region $(n=1981)$. Based on retrospective data analysis ("Uniform-Agri" - program of dairy herd management) for the period from 2004 to 2017 it was studied the live weight of cows in growing period (newborns, 6, 12; 18 months, at first insemination and after the first calving), body measurements of heifers (height at shoulders, chest depth, chest width, chest girth behind the shoulder blades, oblique body length, width of hips, wrist girth) and traits of reproducibility (age at first insemination, age at first calving, duration of service period, insemination index, fertility index) and milk productivity of cows (milk yields for 305 days, fat and protein content in milk for the first, second and third lactation). Based on our previously obtained data by correlation analysis method it was studied the relative variability of phenotypic traits and indicators of dairy productivity of cows. It is established that the connections of live weight of cows during their rearing with traits of milk productivity were multidirectional and ranged from slightly improbable to moderately significant values. At the same time, in both farms, the most significant highly probable connection was noted between the live weight of animals at the age of 12 months and the milk yield of first-borns that indicates the possibility of selecting heifers at the specified age to provide them future high milk productivity. There was significant variability of the relationship between body measurements and the amount of milk yield of cows for the first, second and third lactation. However, cows of both farms, had direct connection, but a bit weaker in animals at PJSC "Breeding Plant "Stepnoy". Positive correlation coefficients between indicators of exterior and milk yields of cows give reasons to claim the efficiency of indirect selection of heifers by body measurements. Rational management of dairy farming and high profits depend a lot on knowledge of regularities of correlative variability of productive traits of cows and indicators of reproductive capacity. It is established that the connections between the traits of milk productivity and reproductive capacity of animals were different and ranged from weak to medium and from reliable to improbable. The most significant highly reliable, however, with negative correlation coefficients were observed between milk yield of cows for all studied lactations and their age at the first insemination and the first calving.

Key words: cows, correlative variability, dairy productivity, live weight, body measurements, reproductive capacity.

\section{Співвідносна мінливість фенотипових ознак та показників молочної продуктивності корів}

\author{
Є. І. Федорович ${ }^{1}$ В. В. Федорович ${ }^{1}$, П. В. Боднар ${ }^{2}$, С. І. Филь ${ }^{3}$, А. В. Димчук ${ }^{4}$, Т. В. Оріхівський ${ }^{2}$
}


${ }^{1}$ Інститут біології тварин НААН, м. Львів, Україна

${ }^{2}$ Львівський національний університет ветеринарної медицини та біотехнологій імені С. 3. Гюсииького, м. Львів, Україна

${ }^{3}$ Dairy Global Experts (ТОВ “Дейрі Глобал Експертс”), м. Умань, Украӥна

${ }^{4}$ Подільський державний аграрно-технічний університет, м. Кам'янеиь-Подільський, Украӥна

Дослідження проведені на чорно-рябій худобі (голштинська та украӥнська чорно-ряба молочна породи) ТОВ “Велетень” Глухівського району Сумської області $(n=1956)$ та ПАТ “Племзавод “Стєпной” Кам'янсько-Дніпровського району Запорізької області $(n=$ 1981). У піддослідних корів на основі ретроспективного аналізу даних за період з 2004 по 2017 рр. (програма управління молочним стадом "Юніформ-Агрі") вивчали живу масу корів у період вирощування (новонароджені, 6, 12; 18 місячів, при першому осіменінні та після першого отелення), проміри тіла корів-первісток (висота в холиі, глибина грудей, ширина грудей, обхват грудей за лопатками, коса довжина тулуба, ширина в маклаках, обхват п'ястка) і ознаки відтворювальної здатності (вік при першому осіменінні, вік при першому отеленні, тривалість сервіс-періоду, індекс осіменіння, індекс плодючості) та молочної продуктивності корів (надій за 305 днів, вміст жиру і білка в молочі за першу, другу і третю лактації). На основі одержаних нами раніше даних методом кореляційного аналізу вивчали співвідносну мінливість фенотипових ознак та показників молочної продуктивності корів. Встановлено, щңо зв'язки живої маси корів у період їх вирощування з ознаками молочної продуктивності мали різноспрямований характер $і$ коливалися від незначного невірогідного до середнього достовірного значень. При иьому в обох господарствах найсуттєвіший високовірогідний зв'язок було виявлено між живою масою тварин у віці 12 місяиів та надоєм первісток, що свідчить про можливість добору телиць у зазначеному вічі для забезпечення їхньої майбутньої високої молочної продуктивності. Спостерігалася істотна варіабельність зв'язку між промірами тіла та величиною надою корів за периу, другу та третю лактації. Втім, у корів обох господарств цей зв'язок був прямим, проте дещо слабший у тварин ПАТ “Племзавод “Стєпной”. Додатні коефіцієнти кореляиї̈ між показниками екстер'єру та надоєм корів дають підстави стверджувати про ефективність непрямого добору первісток за промірами тіла. Важливим для раціонального ведення молочного скотарства й одержання високих прибутків є знання закономірностей співвідносної мінливості продуктивних ознак корів та показників відтворювальної здатності. Встановлено, щя зв'язки між ознаками молочної продуктивності та репродуктивної здатності тварин були різновекторними і коливалися від слабких до середніх та від достовірних до невірогідних. Найсуттєвіші високодостовірні, проте від'ємні коефіиієнти кореляиії спостерігалися між надоєм корів за всі досліджувані лактації та їх віком при першому осіменінні й периому отеленні.

Ключові слова: корови, співвідносна мінливість, молочна продуктивність, жива маса, проміри тіла, відтворювальна здатність.

\section{Вступ}

Зв'язки між селекційними ознаками тварин цікавлять як практиків, так і вчених, оскільки вони пов'язані між собою певним співвідношенням i змінюються внаслідок постійного добору людиною чи природою. Результати досліджень науковців співвідносної мінливості дають можливість встановити напрям селекції та добору тварин за окремими ознаками, що забезпечить покращення екстер'єру і підвищення продуктивності худоби вітчизняних порід (Bardash, 2019; Poslavska et al., 2016a; Voitenko et al., 2019; Skoromna et al., 2020). 3a даними А. П. Кругляка, Т. О. Кругляк (Krugliak \& Krugliak, 2019), зв’язки між промірами тіла і ознаками молочної продуктивності тварин змінюються у процесі ïх удосконалення та певною мірою визначаються напрямом і рівнем їхньої продуктивності. О. В. Бойко та iн. (Boyko et al., 2015) встановлено існування позитивної кореляції та високу достовірність за оцінкою сполучної мінливості корів “промір тіла-надій” у віці першої лактації, що забезпечить ведення ефективної селекції молочної худоби в цьому напрямку. Дослідження співвідносної мінливості групових та описових ознак екстер'єру з надоєм підтверджують наукові праці Л. М. Хмельничого та його учнів (Khmelnychyi, 2018; Karpenko, 2020; Khmelnychyi \& Khmelnychyi, 2021), які свідчать про можливість і доцільність одночасної селекції за продуктивністю та типом, що також дозволить отримати не лише конституціонально міцних і здорових тварин, а й високопродуктивних за надоєм.

Одним 3 найважливіших елементів племінної роботи, спрямованої на поліпшення будь-якої породи, $\epsilon$ правильне вирощування молодняку. Генетично запрограмована продуктивність може бути реалізована лише за сприятливих умов вирощування, догляду та використання тварин. Інтенсивність росту телиць залежить також від генотипових чинників, а також тісно пов'язана 3 рівнем молочної продуктивності (Laduka et al., 2010; Romanenko et al., 2010; Poslavska et al., 2016b; Fedorovych et al, 2016). Багатьма вченими (Gil et al., 2018; Polupan \& Siriak, 2019, Ferenz et al., 2018; Han et al., 2021) доведено, що між інтенсивністю росту телиць та їхньою майбутньою молочною продуктивністю існує кореляційна залежність.

Однією з важливих господарськи корисних ознак корів $\epsilon$ відтворювальна здатність, яка значною мірою визначає їхні продуктивні якості (Fedorovych et al., 2014; Fedorovych et al., 2017; Kochuk-Yashchenko et al., 2018; Shulyar, 2019).

Ряд дослідників засвідчують, що якщо між двома селекційними ознаками сполучна мінливість додатна, то ефективність селекції сільськогосподарських тварин істотно зростає, позаяк за високого ступеня кореляції між двома ознаками добір за однією з них сприяє збільшенню іншої, пов'язаної 3 нею (Rudyk \& Oleshko, 2010; Stavetska \& Dynko, 2016).

Метою досліджень було вивчення співвідносної мінливості ознак живої маси корів у період вирощування, промірів тіла корів-первісток, відтворювальної здатності та молочної продуктивності корів.

\section{Матеріал і методи досліджень}

Дослідження проведені на чорно-рябій худобі (голштинська та українська чорно-ряба молочна породи) ТОВ “Велетень” Глухівського району Сумської області (n = 1956) та ПАТ “Племзавод “Стєпной” Кам'янськоДніпровського району Запорізької області (n = 1981). 
Утримання корів в обох господарствах безприв'язнобоксове. Годівлю тварин проводили за раціонами, які забезпечували основні елементи живлення за існуючими нормами (Pervov \& Smekalov, 2007). У ТОВ “Велетень" доїння корів проводиться у доїльних залах типу “Ялинка” фірми GEA Farm Technologies, 2 х 14 гол. зі швидким виходом, а у ПАТ “Племзавод "Стєпной” - типу "Паралель" фірми DeLavel, 2 x 20 гол.

У підконтрольних корів на основі ретроспективного аналізу даних за період з 2004 по 2017 рр. (програма управління молочним стадом “Юніформ-Агрі”) в попередніх дослідженнях було вивчено живу масу корів у період вирощування (новонароджені, 6, 12; 18 місяців, при першому осіменінні та після першого отелення) (Fyl et al., 2019b), проміри тіла у період першої лактації (висота в холці, глибина грудей, ширина грудей, обхват грудей за лопатками, коса довжина тулуба, ширина в маклаках, обхват п'ястка) (Fedorovych et al., 2019c), ознаки відтворювальної здатності (вік при першому осіменінні, вік при першому отеленні, тривалість сервіс-періоду, індекс осіменіння, індекс плодючості) (Fyl et al., 2018a; Fedorovych et al., 2019b; Fedorovych et al., 2019f; Fyl, 2019b) та молочну продуктивність (надій за 305 днів, вміст жиру і білка в молоці за першу, другу і третю лактаціï) (Fyl et al., 2018b; Fedorovych et al., 2019a; Fedorovych et al., 2019d; Fedorovych et al., 2019e; Fyl, 2019a; Fyl et al., 2019a; Fyl et al., 2019c).

На основі одержаних нами раніше даних методом кореляційного аналізу вивчали співвідносну мінливість фенотипових ознак та показників молочної продуктивності корів.

Обчислення здійснювали методами математичної статистики 3 використанням програмного пакету "STATISTICA 6.1".

\section{Результати та їх обговорення}

Результати наших досліджень свідчать, що зв'язки живої маси корів у період їх вирощування з ознаками молочної продуктивності носили різнонаправлений характер і коливалися від незначного невірогідного до середнього достовірного значень (табл. 1).

\section{Таблиця 1}

Зв'язок живої маси корів у період вирощування з ознаками їхньої подальшої молочної продуктивності, $\mathrm{r} \pm \mathrm{m}_{\mathrm{r}}$

\begin{tabular}{|c|c|c|c|c|c|c|c|c|c|}
\hline \multirow{3}{*}{$\begin{array}{c}\text { Жива маса } \\
\text { тварин, } \\
\text { місяці }\end{array}$} & \multirow{3}{*}{$\begin{array}{l}\text { Лак- } \\
\text { тація }\end{array}$} & \multirow{3}{*}{$\mathrm{n}$} & \multicolumn{3}{|c|}{$\begin{array}{l}\text { Коефіцієнти кореляції живої маси корів у пері- } \\
\text { од їх вирощування з: }\end{array}$} & \multirow{3}{*}{$\mathrm{n}$} & \multicolumn{3}{|c|}{$\begin{array}{c}\text { Коефіцієнти кореляції живої маси корів у } \\
\text { період їх вирощування з: }\end{array}$} \\
\hline & & & надоєм & $\begin{array}{c}\text { вмістом жиру в } \\
\text { молоці }\end{array}$ & $\begin{array}{c}\text { вмістом білка } \\
\text { в молоці } \\
\end{array}$ & & надоєм & $\begin{array}{c}\text { вмістом жиру } \\
\text { молоці }\end{array}$ & $\begin{array}{c}\text { в вмістом білка } \\
\text { в молоці }\end{array}$ \\
\hline & & & \multicolumn{3}{|c|}{ ТОВ “Велетень" } & & \multicolumn{3}{|c|}{ ПАТ “Племзавод “Стєпной”” } \\
\hline \multirow{4}{*}{$\begin{array}{l}\text { новона- } \\
\text { роджені }\end{array}$} & I & 1956 & $0,10 \pm 0,009^{* * *}$ & $-0,01 \pm 0,000$ & $-0,02 \pm 0$, & 1981 & $0,19 \pm 0,036^{* * *}$ & $0,02 \pm 0,000$ & $-0,03 \pm 0,001$ \\
\hline & II & 1324 & $0,07 \pm 0,004^{* *}$ & $0,05 \pm 0,003$ & $-0,06 \pm 0,003^{*}$ & 1123 & $0,12 \pm 0,014^{* * *}$ & $-0,03 \pm 0,001$ & $0,02 \pm 0,000$ \\
\hline & III & 769 & $0,02 \pm 0,000$ & $0,05 \pm 0,002$ & $0,01 \pm 0,000$ & 560 & $0,01 \pm 0,000$ & $0,06 \pm 0,003$ & $-0,03 \pm 0,001$ \\
\hline & I & 1956 & $0,22 \pm 0,050^{* * *}$ & $-0,07 \pm 0,005^{* *}$ & $-0,05 \pm 0,002^{*}$ & 1981 & $0,29 \pm 0,084^{* * *}$ & $-0,03 \pm 0,001$ & $-0,07 \pm 0,006^{* * *}$ \\
\hline \multirow[t]{3}{*}{6} & II & 1324 & $0,17 \pm 0,030^{* * *}$ & $-0,02 \pm 0,000$ & & 1123 & $0,18 \pm 0,034^{* * *}$ & $-0,06 \pm 0,004^{*}$ & $-0,07 \pm 0,006^{* *}$ \\
\hline & III & 769 & & & & 560 & & & \\
\hline & I & 1956 & $* * *$ & $-0,14$ & $-0,07 \pm 0,006^{* * *}$ & 1981 & $0,206^{* * *}$ & $-0,05 \pm 0,002^{*}$ & $0,006^{* * *}$ \\
\hline \multirow[t]{3}{*}{12} & II & 1324 & ${ }^{* * *}$ & $-0,1$ &, 000 & 1123 & $8^{* * *}$ & & $007^{* *}$ \\
\hline & III & 769 & 0 , & & 0 & 560 & *** & & 00 \\
\hline & I & 1956 & $0,24 \pm$ & $-0,07 \pm 0$ & $003^{*}$ & 1981 & $4^{* * *}$ & -0 & 002 \\
\hline \multirow[t]{2}{*}{18} & II & 1324 & $0,20 \pm 0,040^{* * *}$ & $-0,06 \pm 0,004^{*}$ & $0,0 \pm 0,000$ & 1123 & $0,21 \pm 0,045^{* * *}$ & $-0,05 \pm 0,003$ & $-0,06 \pm 0,003$ \\
\hline & III & 769 & $0,125 \pm 0,016^{* * *}$ & $0,01 \pm 0,000$ & $-0,02 \pm$ & 560 & $0,09 \pm 0,008^{*}$ & $0,01 \pm 0,000$ & 002 \\
\hline при пер- & I & 1956 & $-0,39 \pm 0,150^{* * *}$ & $0,129 \pm 0,017^{* * *}$ & $0,06 \pm 0,004^{* *}$ & 1981 & $-0,36 \pm 0,127^{* * *}$ & $0,04 \pm 0,001$ & $0,07 \pm 0,005^{* * *}$ \\
\hline шому & II & 1324 & $-0,27 \pm 0,073^{* * *}$ & $0,07 \pm 0,005^{* *}$ & $0,04 \pm 0,002$ & 1123 & $-0,31 \pm 0,093^{* * *}$ & $0,02 \pm 0,000$ & $0,05 \pm 0,002$ \\
\hline осіменінні & III & 769 & $-0,14 \pm 0,021^{* * *}$ & $-0,04 \pm 0,001$ & $0,00 \pm 0,000$ & 560 & $-0,12 \pm 0,014^{* *}$ & $-0,09 \pm 0,009^{*}$ & $-0,06 \pm 0,003$ \\
\hline після & I & 1956 & $-0,33 \pm 0109^{* * *}$ & $0,127 \pm 0,016^{* * *}$ & $0,06 \pm 0003^{* *}$ & 1981 & $-0,20 \pm 0,041^{* * *}$ & $-0,00 \pm 0,000$ & $0,04 \pm 0,002$ \\
\hline першого & II & 1324 & $-0,30 \pm 0,092^{* * *}$ & $0,06 \pm 0,004^{*}$ & $0,07 \pm 0,005^{* *}$ & 1123 & $-0,26 \pm 0,067^{* * *}$ & $-0,02 \pm 0,001$ & $0,05 \pm 0,002$ \\
\hline отелення & III & 769 & $-0,19 \pm 0,037^{* * *}$ & $0,01 \pm 0,000$ & $0,06 \pm 0,004$ & 560 & $-0,13 \pm 0,017^{* *}$ & $-0,10 \pm 0,011^{* *}$ & $-0,07 \pm 0,006$ \\
\hline
\end{tabular}

При цьому найсуттєвіші додатні і високовірогідні зв'язки спостерігалися між живою масою тварин ТОВ "Велетень" у 6-, 12- і 18-місячному віці та надоєм: залежно від лактації та віку вони коливалися від 0,09 до 0,38. Обернена кореляція була виявлена між живою масою при першому осіменінні й після першого отелення та надоєм і вона, залежно від лактації, перебувала відповідно в межах -0,14--0,39 та -0,19- -0,33 за високодостовірного рівня. Найслабше, проте здебільшого вірогідно, надій корелював 3 живою масою новонароджених тварин.

У ПАТ "Племзавод “Стєпной” співвідносна мінливість живої маси тварин у 6, 12 і 18 місяців та надою за першу-третю лактації коливалася від 0,09 до 0,45 і майже у всіх випадках була високовірогідною.
Жива маса новонароджених тварин також високодостовірно корелювала 3 надоєм за першу і другу лактації, проте з надоєм за третю лактацію зв'язок був майже відсутній. Коефіцієнти кореляції між живою масою при першому осіменінні й після першого отелення та надоєм за досліджувані лактації були від’ємними вірогідними (P < 0,01-0,001) і перебували відповідно в межах $-0,12--0,36$ та -0,13- -0,26.

Втім, варто зазначити, що в обох господарствах найсуттєвіший високовірогідний зв'язок було виявлено між живою масою тварин у віці 12 місяців та надо$\epsilon м$ первісток, що свідчить про можливість добору телиць у зазначеному віці для забезпечення їхньої майбутньої високої молочної продуктивності. Водночас між вмістом жиру й білка в молоці та живою ма- 
сою корів у період їх вирощування виявлені різноспрямовані слабкої сили зв'язки, причому в більшості випадків вони були недостовірними.

У сучасній практичній селекції молочної худоби за екстер'єром мають цінність насамперед ті проміри тіла, які безпосередньо або в комплексі позитивно впливають на продуктивність тварин. Пошук зв'язків між екстер'єром і продуктивністю тварин зумовлений не лише необхідністю вести селекцію на поліпшення будови тіла, а й на пошуки окремих ознак селекції, за якими можна опосередковано підвищувати їхню продуктивність (Laduka et al., 2010).

Нами встановлена істотна варіабельність зв'язку між промірами тіла та величиною надою корів за першу, другу та третю лактації (табл. 2). У ТОВ “Велетень" виявлено прямий зв'язок промірів тіла первісток 3 надоєм і різноспрямований - 3 вмістом жиру й білка в молоці. Зі ступенем достовірності (P $<0,05-$ $0,001)$ надій корів за досліджувані лактації корелював 3 промірами обхвату грудей за лопатками ( $\mathrm{r}=0,26-$ $0,37)$, косої довжини тулуба $(\mathrm{r}=0,19-0,26)$ та ширини в маклаках $(\mathrm{r}=0,18-0,28)$. У ПАТ “Племзавод “Стєпной” співвідносна мінливість промірів тіла та надою корів у більшості випадків відрізнялася істотно меншим рівнем в межах досліджуваних лактацій, ніж у тварин ТОВ “Велетень”.

\section{Таблиця 2}

Зв’язок промірів тіла корів-первісток з ознаками їхньої подальшої молочної продуктивності, $\mathrm{r} \pm \mathrm{m}_{\mathrm{r}}$

\begin{tabular}{|c|c|c|c|c|c|c|c|c|c|}
\hline \multirow{3}{*}{$\begin{array}{c}\text { Назва } \\
\text { проміру }\end{array}$} & \multirow{3}{*}{$\begin{array}{l}\text { Лак- } \\
\text { тація }\end{array}$} & \multirow{3}{*}{$\mathrm{n}$} & \multicolumn{3}{|c|}{ Коефіцієнти кореляції промірів тіла корів з: } & \multirow{3}{*}{$\mathrm{n}$} & \multicolumn{3}{|c|}{ Коефіцієнти кореляції промірів тіла корів з: } \\
\hline & & & надоєм & $\begin{array}{c}\text { вмістом жиру в } \\
\text { молоці }\end{array}$ & $\begin{array}{c}\text { вмістом білка } \\
\text { в молоці }\end{array}$ & & $\mathrm{H}$ & $\begin{array}{c}\text { вмістом жиру } \\
\text { в молоці }\end{array}$ & $\begin{array}{c}\text { вмістом білка } \\
\text { в молоці }\end{array}$ \\
\hline & & & \multicolumn{3}{|c|}{ ТОВ “Велетень" } & & \multicolumn{3}{|c|}{ ПАТ “Племзавод “Стєпной””' } \\
\hline \multirow{3}{*}{$\begin{array}{c}\text { Висота в } \\
\text { холці }\end{array}$} & I & 302 & $0,13 \pm 0,017^{*}$ & $0,02 \pm 0,006$ & $-0,01 \pm 0,000$ & 284 & $0,04 \pm 0,001$ & $0,04 \pm 0,002$ & $-0,05 \pm 0,003$ \\
\hline & II & 237 & $0,17 \pm 0,027^{* *}$ & $0,09 \pm 0,009$ & $0,01 \pm 0,000$ & 149 & $0,05 \pm 0,002$ & $0,05 \pm 0,002$ & $0,03 \pm 0,001$ \\
\hline & III & 122 & $0,11 \pm 0,012$ & $-0,19 \pm 0,037^{*}$ & $-0,04 \pm 0,002$ & 84 & $0,08 \pm 0,007$ & $-0,03 \pm 0,001$ & $0,03 \pm 0,001$ \\
\hline \multirow{3}{*}{$\begin{array}{l}\text { Глибина } \\
\text { грудей }\end{array}$} & I & 302 & $0,06 \pm 0,004$ & $0,01 \pm 0,000$ & $0,01 \pm 0,000$ & 284 & $0,07 \pm 0,004$ & $0,11 \pm 0,011$ & $-0,11 \pm 0,012$ \\
\hline & II & 237 & $0,08 \pm 0,006$ & $0,07 \pm 0,004$ & $0,14 \pm 0,020^{*}$ & 149 & $0,12 \pm 0,015$ & $-0,08 \pm 0,007$ & $-0,01 \pm 0,000$ \\
\hline & III & 122 & $0,02 \pm 0,000$ & $-0,22 \pm 0,049^{* *}$ & $-0,16 \pm 0,024$ & 84 & $0,15 \pm 0,023$ & $-0,10 \pm 0,011$ & $-0,05 \pm 0,006$ \\
\hline \multirow{3}{*}{$\begin{array}{l}\text { Ширина } \\
\text { грудей }\end{array}$} & I & 302 & $0,10 \pm 0,010$ & $0,16 \pm 0,026^{* *}$ & $0,03 \pm 0,001$ & 284 & $0,15 \pm 0,022^{* *}$ & ${ }^{*} 0,05 \pm 0,003$ & $0,06 \pm 0,004$ \\
\hline & II & 237 & $0,10 \pm 0,009$ & $0,16 \pm 0,024^{*}$ & $0,11 \pm 0,012$ & 149 & $0,18 \pm 0,032^{*}$ & $0,01 \pm 0,000$ & 007 \\
\hline & III & 122 & $0,13 \pm 0,017$ & $-0,03 \pm 0,001$ & $-0,04 \pm 0,002$ & 84 & $0,12 \pm 0,013$ & $0,10 \pm 0,009$ & $0,01 \pm 0,000$ \\
\hline $\mathrm{O}$ & I & 302 & $0,26 \pm 0,068^{* * *}$ & $0,03 \pm 0,001$ & $0,01 \pm 0,000$ & 284 & $0,14 \pm 0,019^{*}$ & $-0,02 \pm 0,000$ & 0,003 \\
\hline гру & II & 237 & $0,37 \pm 0,138^{* * *}$ & $0,14 \pm 0,021^{*}$ & $0,10 \pm 0,010$ & 149 & $0,12 \pm 0,015$ & $-0,15 \pm 0,024$ & 0,004 \\
\hline & III & 122 & $0,28 \pm 0,076^{* *}$ & $0,02 \pm 0,000$ & $-0,19 \pm 0,037^{*}$ & 84 & & $-0,08 \pm 0,007$ & 007 \\
\hline Ko & I & 302 & $0,20 \pm 0,03$ & $0,02 \pm$ & $0,03 \pm 0,001$ & 284 & 0,17 & $-0,10 \pm 0,009$ & $-0,0$ \\
\hline довжина & II & 237 & $0,26 \pm$ & & & 149 & & 0,002 & \\
\hline & III & 122 & $0,19 \pm$ & & $-0,18 \pm$ & 84 & & $-0,12 \pm 0,013$ & \\
\hline \multirow{3}{*}{$\begin{array}{l}\text { Ширина в } \\
\text { маклаках }\end{array}$} & I & 302 & $0,19 \pm 0,038^{* * *}$ & $0,09 \pm 0,008$ & $0,04 \pm$ & 284 & $0,14 \pm$ & $0,00 \pm 0,000$ & 000 \\
\hline & II & 237 & $0,18 \pm 0,032^{* *}$ & $0,07 \pm 0,005$ & $0,12 \pm$ & 149 & $0,23 \pm 0,051^{* *}$ & ${ }^{*}-0,02 \pm 0,001$ & 0,09 \\
\hline & III & 122 & $0,28 \pm 0,078^{* *}$ & $-0,12 \pm 0,014$ & $-0,03 \pm 0,001$ & 84 & $0,16 \pm 0,024$ & $0,03 \pm 0,001$ & $-0,08 \pm 0,006$ \\
\hline \multirow{3}{*}{$\begin{array}{l}\text { Обхват } \\
\text { п’ястка }\end{array}$} & I & 302 & $0,00 \pm 0,000$ & $0,01 \pm 0,000$ & $0,04 \pm 0,002$ & 284 & $0,01 \pm 0,000$ & $0,01 \pm 0,000$ & $0,03 \pm 0,001$ \\
\hline & II & 237 & $0,10 \pm 0,010$ & $-0,04 \pm 0,002$ & $0,06 \pm 0,004$ & 149 & $0,21 \pm 0,044^{* *}$ & ${ }^{*}-0,02 \pm 0,001$ & $0,01 \pm 0,000$ \\
\hline & III & 122 & $0,03 \pm 0,001$ & $-0,03 \pm 0,001$ & $0,03 \pm 0,001$ & 84 & $0,01 \pm 0,001$ & $0,04 \pm 0,001$ & $-0,04 \pm 0,001$ \\
\hline
\end{tabular}

При цьому порівняно вищий і достовірний зв'язок (Р $<0,05-0,001)$ надою встановлено з промірами ширини грудей за першу й другу лактації ( $\mathrm{r}=0,15$ та $\mathrm{r}=0,18)$, ширини в маклаках за ці ж лактації ( $\mathrm{r}=0,14$ та $\mathrm{r}=0,23)$, обхвату грудей за лопатками за першу лактацію $(\mathrm{r}=0,14)$ та косої довжини тулуба й обхвату п'ястка за другу лактації ( $\mathrm{r}=0,23$ та $\mathrm{r}=0,21$ відповідно).

Між промірами тіла та вмістом жиру й білка в молоці зв'язок був слабким і різнонаправленим, що вказує на те, що ці ознаки молочної продуктивності більшою мірою детермінуються середовищними та генетичними чинниками.

Для забезпечення високих надоїв важливим є знання закономірностей зв'язку ознак молочної продуктивності та відтворювальної здатності корів, що дає можливість раціонально вести молочне скотарст- во й отримувати господарством максимально можливі прибутки.

Встановлено, що найбільш суттєві високовірогідні, проте обернені зв'язки в стадах ТОВ “Велетень” та ПАТ “Племзавод “Стєпной” (табл. 3) спостерігалися між надоєм корів за досліджувані лактації та віком при першому осіменінні $(\mathrm{r}=-0,22--0,37$ та $\mathrm{r}=-0,16-$ $-0,33$ відповідно) й першому отеленні (r = -0,23- -0,37 та $r=-0,16--0,32)$. Значно менші, але додатні й майже в усіх випадках достовірні (Р $<0,05-0,001)$ коефіцієнти кореляції виявлені між надоєм та тривалістю сервіс-періоду, індексом осіменіння й індексом плодючості корів. Фенотипова кореляція між досліджуваними ознаками відтворювальної здатності тварин та вмістом жиру й білка в молоці була ще меншою і різною за спрямованістю $з$ коливаннями від достовірного до невірогідного рівня. 
Таблищя 3

Співвідносна мінливість ознак відтворювальної здатності та молочної продуктивності корів, $\mathrm{r} \pm \mathrm{m}_{\mathrm{r}}$

\begin{tabular}{|c|c|c|c|c|c|c|c|c|c|}
\hline \multirow{3}{*}{$\begin{array}{c}\text { Ознака } \\
\text { відтворю- } \\
\text { вальної } \\
\text { здатності } \\
\text { тварин }\end{array}$} & \multirow{3}{*}{$\begin{array}{l}\text { Лак- } \\
\text { тація }\end{array}$} & \multirow{3}{*}{$\mathrm{n}$} & \multicolumn{3}{|c|}{$\begin{array}{l}\text { Коефіцієнти кореляції ознак відтворювальної } \\
\text { здатності з: }\end{array}$} & \multirow{3}{*}{$\mathrm{n}$} & \multicolumn{3}{|c|}{$\begin{array}{l}\text { Коефіцієнти кореляції ознак відтворювальної } \\
\text { здатності з: }\end{array}$} \\
\hline & & & надо & $\begin{array}{r}\text { вмістом } x \\
\text { в моло } \\
\end{array}$ & $\begin{array}{c}\text { вмістом білка } \\
\text { в молоці }\end{array}$ & & надс & $\begin{array}{l}\text { вмістом жиру } \\
\text { в молоці }\end{array}$ & $\begin{array}{l}\text { білка } \\
\text { оці }\end{array}$ \\
\hline & & & \multicolumn{3}{|c|}{ ТОВ “Велетень” } & & \multicolumn{3}{|c|}{ ПАТ “Племзавод “Стєпной””” } \\
\hline & I & & & & & & & & \\
\hline & II & & & & & & & & \\
\hline ocim & III & & & & & & & & \\
\hline & I & & & & & 19 & & & \\
\hline & II & & & & & 1 & & & \\
\hline & III & & & & & 560 & & & \\
\hline \multirow{3}{*}{$\begin{array}{c}\text { Тривалість } \\
\text { сервіс- } \\
\text { періоду }\end{array}$} & $\mathrm{I}$ & & & & & 1726 & & & \\
\hline & II & & & & & 92 & & & \\
\hline & III & 593 & & & & 47 & & & $17^{* *}$ \\
\hline \multirow{3}{*}{$\begin{array}{c}\text { Індекс } \\
\text { осіменіння }\end{array}$} & I & 1739 & $0,06 \pm$ & $-0,02 \pm$ & & 1726 & 0,08 & & \\
\hline & II & 1087 & & & & 926 & 0,16 & & \\
\hline & III & & & & & 478 & & & $014^{* *}$ \\
\hline \multirow{3}{*}{$\begin{array}{c}\text { Індекс } \\
\text { плодючості }\end{array}$} & I & 1739 & $0,19 \pm 0,034^{* * *}$ & $-0,02 \pm 0,000$ & $-0,07 \pm 0,004^{* *}$ & 1726 & $0,14 \pm 0,022^{* * *}$ & $-0,01$ & $-0,2 \pm 0,000$ \\
\hline & 11 & 1087 & & & & & & & $-0,0$ \\
\hline & III & 593 & $0,02 \pm 0,000$ & $-0,04 \pm 0,001$ & $0,03 \pm 0,000$ & 478 & $0,04 \pm 0,002$ & $0,09 \pm 0,007$ & $0,12 \pm 0,015^{* *}$ \\
\hline
\end{tabular}

\section{Висновки}

1. В обох господарствах найсуттєвіший високовірогідний зв'язок було виявлено між живою масою тварин у віці 12 місяців та надоєм первісток, що свідчить про можливість добору телиць у зазначеному віці для забезпечення їхньої майбутньої високої молочної продуктивності, а додатні коефіцієнти кореляції між показниками екстер'єру та надоєм корів дають підстави стверджувати про ефективність непрямого добору первісток за промірами тіла.

2. Зв'язки між ознаками молочної продуктивності та репродуктивної здатності тварин були різновекторними і коливалися від слабких до середніх та від достовірних до невірогідних. Найсуттєвіші високодостовірні, проте від’ємні коефіцієнти кореляції спостерігалися між надоєм корів за всі досліджувані лактації та їхнім віком при першому осіменінні й першому отеленні.

Перспективи подальших досліджень. У подальшому буде вивчено молочну продуктивність корів за внутрішньолінійного розведення та кросів ліній.

\section{References}

Bardash, D. O. (2019). Populiatsiino-henetychni parametry oznak molochnoi produktyvnosti koriv ukrainskykh chervono-riaboi ta chorno-riaboi molochnykh porid [Population-genetic parameters of dairy productivity traits of cows of Ukrainian Redand-White and Black-and-White dairy breeds]. Visnyk Sumskoho natsionalnoho ahrarnoho universytetu. Seriia: Tvarynnytstvo, 3(38), 73-77. doi: 10.32845/bsnau.lvst.2019.3.9 (in Ukrainian).

Boyko, O. V., Sotnichenko, Y. M., \& Tkach, E. F. (2015). Uspadkuvannia ta spivvidnosna minlyvist statei eksterieru koriv molochnykh porid [Inheritance and comparable of variability of articles exterior dairy breed cows]. Rozvedennya i henetyka tvaryn, 49, 69-75. URL:
http://digest.iabg.org.ua/images/digest/49/Animal_bre eding_and_genetics_49.pdf\#page=69 (in Ukrainian).

Fedorovych, Y., Fyl, S., \& Bodnar, P. (2019f). Vidtvoriuvalna zdatnist molochnoi khudoby riznykh heneratsii u vysokoproduktyvnykh stadakh [Reproductive capacity of the dairy cattle of different generations of high-productive herds]. Tvarynnytstvo Ukrainy, 3-4, 12-17. URL: https://tvarynnyctvoua.at.ua/TU_3-42019.pdf\#page $=12$ (in Ukrainian).

Fedorovych, Y., Shcherbatyj, Z., \& Bodnar, P. (2014). Vplyv pokaznykiv vidtvornoi zdatnosti na molochnu produktyvnist koriv. Tvarynnytstvo Ukrainy, 2, 38-41. URL: http://nbuv.gov.ua/UJRN/TvUkr_2014_2_13 (in Ukrainian).

Fedorovych, E. I., Fyl, S. I., \& Bodnar, P. V. (2019c). Exterior special characteristics of cows and their descendants of different generations at high-producing herds. Scientific Messenger of Lviv National University of Veterinary Medicine and Biotechnologies. Series: Agricultural sciences, 21(91), 76-82. doi: 10.32718/nvlvet-a9113.

Fedorovych, E. I., Fyl, S. I., \& Bodnar, P. V. (2019d). Evaluation of the families of dairy herd by the productivity and breeding value. Animal Breeding and Genetics, 58, 58-66. doi: 10.31073/abg.58.08.

Fedorovych, E. I., Fyl, S. I., \& Bodnar, P. V. (2019e). Kharakterystyka rodyn koriv z urakhuvanniam rivnia yikh nadoiu ta pleminnoi tsinnosti [Characteristics of cow families, considering the level of their yields and breeding value]. Tvarynnytstvo ta tekhnolohii kharchovykh produktiv, 10(2), 51-60. doi: 10.31548/animal2019.02.051 (in Ukrainian).

Fedorovych, Y. I., Poslavska, Yu. V., \& Bodnar, P. V. (2016). Zavisimost molochnoj produktivnosti korov ot zhivoj massy v period ih vyrashhivanija. Aktualnye problemy intensivnogo razvitija zhivotnovodstva: sbornik nauchnyh trudov, 19(2), 331-338. URL: https:/elc.baa.by/upload/apirz-19-2-t.pdf\#page=331 ; https://cyberleninka.ru/article/n/zavisimost- 
molochnoy-produktivnosti-korov-ot-zhivoy-massy-vperiod-ih-vyraschivaniya (in Russian).

Fedorovych, Y. I., Poslavska, Yu. V., \& Bodnar, P. V. (2017). Vplyv pokaznykiv vidtvoriuvalnoi zdatnosti koriv na formuvannia yikh molochnoi produktyvnosti [The influence of indicators of cows reproductive ability on the formation of their milk production]. Ahrarna nauka ta kharchovi tekhnolohii, 3(97), 213223. URL: http://nbuv.gov.ua/UJRN/anxt_2017_3_30 (in Ukrainian).

Fedorovych, Y., Fedorovych, V., Mazur, N., Bodnar, P., \& Fil, S. (2019a). The influence of environmental factors on the dairy productivity of cows. Bulletin of Sumy National Agrarian University. The series: Livestock, 3(38), 44-54. doi: 10.32845/bsnau.lvst.2019.3.7.

Fedorovych, Y., Fedorovych, V., Mazur, N., Bodnar, P., \& Fil, S. (2019b) Reproductive ability of cows and their descendants of different generations. Bulletin of Sumy National Agrarian University. The series: Livestock, 4(39), 20-27. doi: 10.32845/bsnau.lvst.2019.4.3.

Ferenz, L. V., Polylikh, M. I., \& Ilnitskaya, G. I. (2018). The influence of living mass of the ukrainian black and white dairy breed cells in various everyday periods on their more dairy productivity. Scientific Messenger of Lviv National University of Veterinary Medicine and Biotechnologies, 20(84), 104-108. doi: $10.15421 /$ nvlvet8419.

Fyl, S. I. (2019a). Dynamika molochnoi produktyvnosti koriv u vysokoproduktyvnykh stadakh. Aktualni doslidzhennia z problem rozvedennia, henetyky ta biotekhnolohii u tvarynnytstvi : materialy XVII Vseukrainskoi naukovoi konferentsii molodykh uchenykh i aspirantiv $\mathrm{z}$ mizhnarodnoiu uchastiu, prysviachenii 80-y richnytsi vid dnia narodzhennia akademika UAAN Valeriia Petrovycha Burkata (Chubynske, 2019), 49-50. URL: http://digest.iabg.org.ua/images/digest/2019/160919.p df\#page=49 (in Ukrainian).

Fyl, S. I. (2019b). Dynamika vidtvoriuvalnoi zdatnosti koriv u vysokoproduktyvnykh stadakh chorno-riaboi khudoby. Problemy vyrobnytstva i pererobky prodovolchoi syrovyny ta yakist i bezpechnist kharchovykh produktiv: zbirnyk naukovykh prats mizhnarodnoi naukovo-praktychnoi konferentsii (m. Zhytomyr, 16-17 travnia 2019 r.), 212-216 (in Ukrainian).

Fyl, S. I., Fedorovych, E. I., \& Bodnar, P. V. (2018a). Reproductive ability of cows and their descendants of different generations. Scientific Messenger of LNU of Veterinary Medicine and Biotechnologies. Series: Agricultural Sciences, 20(89), 114-121. doi: $10.32718 /$ nvlvet8921.

Fyl, S. I., Fedorovych, E. I., \& Bodnar, P. V. (2019a). Dynamics of dairy productivity of cows of different lines. Animal Breeding and Genetics, 57, 136-142. doi: 10.31073/abg.57.16.

Fyl, S. I., Fedorovych, E. I., \& Bodnar, P. V. (2019b). Dynamika rostu zhyvoi masy koriv riznykh heneratsii u period yikh vyroshchuvannia. Naukovoinformatsiinyi visnyk, 12 (Zbirnyk informatsiinykh povidomlen, statei, dopovidei i tez naukovopraktychnykh konferentsii vykladachiv, aspirantiv, mahistriv, studentiv. DVNZ «Khersonskyi derzhavnyi ahrarnyi universytet»), 222-228. URL: http:/www.ksau.kherson.ua/files/documents/Visnyky\% 20BTF/Випуск\%2012.pdf\#page=227 (in Ukrainian).

Fyl, S. I., Fedorovych, E. I., \& Bodnar, P. V. (2019c). Milk productivity of cows-daughters from different bulls. Scientific Messenger of LNU of Veterinary Medicine and Biotechnologies. Series: Agricultural Sciences, 21(90), 68-75. doi: 10.32718/nvlvet-a9012.

Fyl, S. I., Fedorovych, Ye. I., \& Bodnar, P. V. (2018b). Molochna produktyvnist koriv ta yikh nashchadkiv riznykh pokolin [Dairy productivity of cows and their offsprings of different generations]. Visnyk Sumskoho natsionalnoho ahrarnoho universytetu. Seriia: Tvarynnytstvo, 7(35), 55-60. URL: https://nubip.edu.ua/sites/default/files/u104/visnik_su mskogo_nacionalnogo_agrarnogo_universitetu.pdf $\#$ pa $\mathrm{ge}=55$ (in Ukrainian).

Gil, M. I., Galushko, I. A., Karatieieva, O. I., \& Dekhtiar, Yu. F. (2018). Vidtvoriuvalna produktyvnist koriv holshtynskoi porody zalezhno vid typu formuvannia orhanizmu. Zbiór artykulów naykowych recenzowanych: Monografia pokonferencyjna (Warsawa), 6, 12-16. URL: http://dspace.mnau.edu.ua/jspui/bitstream/123456789/47 50/1/Каратеева_Стаття\%20на\%20Польшу.pdf （in Ukrainian).

Han, L., Heinrichs, A. J., De Vries, A., \& Dechow, C. D. (2021). Relationship of body weight at first calving with milk yield and herd life. J. Dairy Sci, 104, 397404. doi: 10.3168/jds.2020-19214.

Karpenko, B. M. (2020) Uspadkovuvanist ta spivvidnosna minlyvist $\mathrm{z}$ nadoiem liniinykh oznak koriv-pervistok holshtynskoi porody [Heritability and correlated variability with milk yield of linear traits firstborn cows of Holstein breed]. Visnyk Sumskoho natsionalnoho ahrarnoho universytetu. Seriia: Tvarynnytstvo, 3(42), 44-50. doi: 10.32845/bsnau.lvst.2020.3.8 (in Ukrainian).

Khmelnychyi, L. M. (2018). Uspadkovuvanist ta spivvidnosna minlyvist liniinykh oznak eksterieru korivpervistok ukrainskoi chervono-riaboi molochnoi porody z nadoiem. Aktualni pytannia tekhnolohii produktsii tvarynnytstva: Zbirnyk statei za rezultatamy III Vseukrainskoi naukovo-praktychnoi internet-konferentsii (m. Poltava, 30-31 zhovtnia 2017 roku), 52-57. URL: https://www.pdau.edu.ua/sites/default/files/academicdepa rtment/kafedra-harchovyh-tehnologiy/zbirnykinternetkon fereciya20181.pdf\#page=52 (in Ukrainian).

Khmelnychyi, L. M., \& Khmelnychyi, S. L. (2021). Population and genetic parameters of linear conformation traits cows firstborn ukrainian blackand-white dairy breed. Bulletin of Sumy National Agrarian University. The series: Livestock, 3(46), 712. doi: 10.32845/bsnau.lvst.2021.3.2.

Kochuk-Yashchenko, O., Lobodzinskyi, V., \& Rafalskyi, Yu. (2018) Vplyv viku pershoho otelennia koriv ukrainskoi chorno-riaboi molochnoi porody na yikh molochnu produktyvnist ta fertylnist. Rozvedennia ta selektsiia tvaryn: dosiahnennia, problemy, perspektyvy: zbirnyk naukovykh prats mizhnarodnoi naukovo-praktychnoi konferentsii (m. Zhytomyr 20 kvitnia 2018 roku), 126-131. URL: http://zt- 
tehnolog.at.ua/zbirnik_zhnaeu_20.04.2018.pdf\#page=1 27 (in Ukrainian).

Krugliak, A. P., \& Krugliak, T. O. (2019) Spivvidnosna minlyvist selektsiinykh oznak tvaryn molochnykh porid khudoby [Correlative variability of selection attributes of animals of dairy breeds of cattle]. Visnyk ahrarnoi nauky, 4(793), 45-51. doi: 10.31073/agrovisnyk201904-07 (in Ukrainian).

Kuziv, M. I., ～\& Fedorovich, E. I. (2014). Zalezhnist molochnoi produktyvnosti koriv ukrainskoi chornoriaboi molochnoi porody vid zhyvoi masy v period yikh vyroshchuvannia [Dependence ofmilkproduction Ukrainian black and white dairy cattle from liveweight duringtheir growth]. Visnyk Sumskoho natsionalnoho ahrarnoho universytetu. Seriia: Tvarynnytstvo, 2/2(25), 68-72. URL: http://nbuv.gov.ua/UJRN/Vsna_tvar $2014 \_2 \% 282 \% 29 \quad 17$ (in Ukrainian).

Laduka, V. I., Khmelnichiy, L. M., \& Salogub, A. N. (2010). Spoluchna minlyvist statei eksterieru koriv Z molochnoiu produktyvnistiu [Correlative changeability of reasons of exterior of cows with the suckling productivity]. Tekhnolohiia vyrobnytstva i pererobky produktsii tvarynnytstva [Animal Husbandry Products Production and Processing]: Zbirnyk naukovykh prats Bilotserkivskoho NAU, 3(72), 9-11. URL: http://repo.sau.sumy.ua/handle/ $123456789 / 2438$ (in Ukrainian).

Normy potrebnostej molochnogo skota v pitatelnyh veshhestvah (2007); perevod s angl. N.G. Pervov, N.A. Smekalov. Moskva (in Russian).

Polupan, Yu. P., \& Siriak, V. A. (2019). Vplyv intensyvnosti formuvannia na zhyvu masu telyts i molochnu produktyvnist koriv [Influence of the intensity of formation on live weight of heifers and milk productivity of cows]. Rozvedennia i henetyka tvaryn, 57, 111-125. doi: 10.31073/abg.57.14 (in Ukrainian).

Poslavska, Y. V., Fedorovych, Y.I., \& Bodnar, P. V. (2016b) Zalezhnist molochnoi produktyvnosti koriv ukrainskoi chorno-riaboi molochnoi porody vid zhyvoi masy i viku pry pershomu osimeninni ta pershomu otelenni [The dependence of milk productivity of ukrainian black-spotted dairy cows breed on the living mass and age at first insemination and first calving]. Visnyk Sumskoho natsionalnoho ahrarnoho universytetu. Seriia: Tvarynnytstvo, 5(29), 89-95. URL: http://nbuv.gov.ua/UJRN/Vsna_tvar_ 2016_5_21 (in Ukrainian).

Poslavska, Y. V., $\quad$ Fedorovych, E. I., \& Bodnar, P. V. (2016a) Vplyv eksterieru koriv-pervistok ukrainskoi chorno-riaboi molochnoi porody na formuvannia yikh podalshoi molochnoi produktyvnosti [Exterior influence of ukrainian black-and-white dairy first-calf heifers on the formation of their further milk productivity]. Rozvedennia i henetyka tvaryn, 51, 131139. URL: http://nbuv.gov.ua/UJRN/rgt_2016_51_20 (in Ukrainian).

Romanenko, O. A., Shcherbatiuk, N. V., \& Dorofieiev, D. Yu. (2010) Vplyv intensyvnosti vyroshchuvannia telyts ukrainskoi chorno-riaboi molochnoi porody na nastupnu molochnu produktyvnist. Zbirnyk naukovykh prats Podilskoho derzhavnoho ahrarno-tekhnichnoho universytetu, 18, 178-180 (in Ukrainian).

Rudyk, I. A., \& Oleshko, V. P. (2010). Fenotypovi zminy u pleminnykh stadakh molochnoi khudoby pid vplyvom henotypovykh ta paratypovykh faktoriv [Phenotypical changes in the pedigree herds of dairy cattle under the influence of genotypic and paratypic factors]. Naukovotekhnichnyi biuleten Instytutu biolohii tvaryn i Derzhavnoho naukovo-doslidnoho kontrolnoho instytutu vetpreparativ ta kormovykh dobavok, 1(11), 229-234. URL: $\quad$ http://archive.inenbiol.com.ua:8080/ntb/ntb4/ pdf/7/3.pdf (in Ukrainian).

Shulyar, A. L. (2019). Vplyv viku pershoho osimeninnia ta pershoho otelennia koriv na yikh molochnu produktyvnist [Influence of age of first insemination and first calving of cows on their milk productivit]. Tavriiskyi naukovyi visnyk, 109(2), 155-161. doi: 10.32851/2226-0099.2019.109-2.25 (in Ukrainian).

Skoromna, O. I., Razanova, O. P., Polishchuk, T. V., Shevchuk, T. V., Bernyk, I. M., \& Paladiichuk, O. R. (2020) Naukovo obhruntovani zakhody pidvyshchennia molochnoi produktyvnosti koriv ta pokrashchennia yakosti syrovyny v umovakh vyrobnytstva: Monohrafiia. URL: http://repository.vsau.org/getfile.php/25356.pdf (in Ukrainian).

Stavetska, R. V., \& Dynko, Yu. P. (2016). Spivvidnosna minlyvist molochnoi produktyvnosti ta promiriv tila pervistok ukrainskoi chorno-riaboi molochnoi porody [Correlative variability of milk production and body measurements of heifers of Ukrainian Black and White dairy cattle]. Tekhnolohiia vyrobnytstva i pererobky produktsii tvarynnytstva [Animal Husbandry Products Production and Processing]: Zbirnyk naukovykh prats Bilotserkivskoho NAU, 1(125), 108-114. URL: http://nbuv.gov.ua/UJRN/tvppt_2016_1_22 (in Ukrainian).

Voitenko, S. L., Karunna, T. I., Shaferivsky, B. S., \& Zheliznyak, I. M. (2019). Vplyv henotypovykh ta paratypovykh faktorivna realizatsiiu molochnoi produktyvnosti koriv [Influence of genotypic and paratype factors on realization of dairy productivity of cows]. Visnyk Sumskoho natsionalnoho ahrarnoho universytetu. Seriia: Tvarynnytstvo, 1-2(36-37), 21-26. doi: 10.32845/bsnau.lvst.2019.1-2.3 (in Ukrainian). 